\title{
UTICAJ STICANJA NOVIH I OTUEENJA POSTOJEĆIH PREDUZEĆA NA IZRADU KONSOLIDOVANIH FINANSIJSKIH IZVEŠTAJA - SLUČAJ TELEKOM SRBIJA A.D.
}

\author{
Nebojša Jeremić, \\ Jovan Bogdanović
}

Telekom Srbija a.d., Beograd, Srbija

\begin{abstract}
Apstrakt:
Izrada konsolidovanih finansijskih izveštaja predstavlja zakonsku obavezu matičnog preduzeća koje ima odgovarajući oblik kontrole nad zavisnim preduzećima. Sam proces konsolidacije podrazumeva spajanje pojedinačnih finansijskih izveštaja članica Grupe uz eliminisanje njihovih međusobnih poslovnih transakcija. Cilj ovog rada je da ukaže na problematiku uvođenja stečenih preduzeća u krug konsolidacije posebno onih koja posluju u delatnostima koja ne odgovaraju delatnosti matičnog preduzeća koje sastavlja konsolidovane finansijske izveštaje. Problematika jednoobraznosti računovodstvenih politika, vrednovanja i prikazivanja pozicija bilansa uspeha i stanja kao i uticaj stečenih/otuđenih preduzeća na imovinu i uspešnost poslovanja Grupe zahtevaju istraživanja kroz različite primere u praksi. Uvođenje preduzeća u krug konsolidacije ili njihovo eliminisanje ima za cilj poboljšanje i optimizaciju performansi poslovanja Grupe. Primeri u praksi nam pokazuju da postoje različiti slučajevi uspešnosti navedenih procesa, što ukazuje na činjenicu da odluka o "širenju" ili "sužavanju" kruga konsolidacije mora biti potkrepljena osnovnim ekonomskim principima.
\end{abstract}

Ključne reči:

statusne promene u Grupi, konsolidacija, finansijsko izveštavanje, računovodstveni standardi.
Korespondencija: Nebojša Jeremić

e-mail:

nebojsaje@telekom.rs

\section{STRUKOVNE I ZAKONSKE OBAVEZE IZRADE KONSOLIDOVANIH FINANSIJSKIH IZVEŠTAJA}

Značajno učešće u osnovnom kapitalu postoji ako jedno lice, samostalno ili sa drugim licima koja sa njim deluju zajedno, poseduje više od $25 \%$ prava glasa u društvu. Većinsko učešće u osnovnom kapitalu postoji ako jedno lice, samostalno ili sa drugim licima koja sa njim deluju zajedno, poseduje više od 50\% prava glasa u društvu. Zakon o privrednim društvima članovima $549,550,551,557,559,560$. i 566 . reguliše pravne osnove povezivanja privrednih društava kao pravnih lica. $\mathrm{Na}$ osnovu odredaba navedenih članova povezana pravna lica čine grupu društava i obuhvataju jedno kontrolno (matično) i podređena (zavisna) društva. Navedenim zakonom, osim pravne osnove povezivanja pravnih lica, nisu regulisana pitanja uređivanja međusobnih odnosa matičnog društva i zavisnih privrednih društava. Zakon o računovodstvu iz 2014. godine definiše obavezu sastavljanja konsolidovanih finansijskih izveštaja za pravna lica koja imaju kontrolu nad jednim ili više zavisnih pravnih lica. U skladu sa ovim Zakonom i sa zahtevima MSFI, pravno lice koje je u ekonomskoj celini matično pravno lice obavezno je da sastavlja, prikazuje, dostavlja i obelodanjuje konsolidovane finansijske izveštaje. Matično preduzeće zajedno sa svojim zavisnim pravnim licima čini grupu koja predstavlja jedinstveni ekonomski entitet. Zavisna preduzeća su pravna lica koja su pod kontrolom drugih pravnih lica, u ovom slučaju matičnog preduzeća. Određivanje kontrole nad drugim pravnim licima je definisano Međunarodnim standardnom finansijskog izveštavanja (MSFI) 10 - Konsolidovani finansijski izveštaji. Cilj navedenog standarda je da obezbedi izradu konsolidovanih finansijskih izveštaja kod svih matičnih pravnih lica koja kontrolišu jedno ili više zavisnih preduzeća. Osnovu za ostvarenje ovog cilja predstavlja definisanje principa kontrole kao kriterijum za konsolidaciju. Suština određivanja kriterijuma se sastoji u identifikaciji da li investitor ima odgovarajući oblik 
kontrole u preduzeće u koje je investirano i zbog toga mora da uključi isto u proces konsolidacije.

Investitor kontroliše preduzeće u koje je investirao ako su ispunjeni sledeći uslovi:

a) moć nad preduzećem u koji je investirao koja podrazumeva prava investitora da usmerava aktivnosti koje značajno utiču na prinose preduzeća u koje je investirano (najčešće se navedeno pravo ostvaruje preko glasačkih prava koja proističu iz vlasničkih instrumenata kapitala);

b) izloženost, ili prava na varijabilne prinose po osnovu svog učešća u preduzeće u koje je uložio (u zavisnosti od performansi poslovanja preduzeća u koje je investirano, prinosi mogu biti pozitivni ili negativni);

c) sposobnost da koristi svoju moć nad preduzećem u koji je investirao kako bi uticao na iznos prinosa za investitora (investitor ima prava za odlučivanje u preduzeću kako bi usmeravajući aktivnosti tog preduzeća u pravom smeru obezbedio sebi što veće prinose tj. povraćaj na uloženi kapital).

Pravilna primena propisanih kriterijuma obezbeđuje potpunost konsolidovanih finansijskih izveštaja i onemogućuje izbegavanje njihovog sastavljanja od strane matičnih pravnih lica. Međunarodni standard finansijskog izveštavanja - MSFI 11 Zajednički aranžmani propisuje principe za finansijsko izveštavanje entiteta koji imaju učešće $u$ aranžmanima koji su pod zajedničkom kontrolom (zajedničko poslovanje i zajednički poduhvat), dok se računovodstveno obuhvatanje učešća u zajedničkim poduhvatima u konsolidovanim finansijskim izveštajima vrši u skladu sa Međunarodnim računovodstvenim standardom - MRS 28 Investicije u pridružene entitete i zajedničke poduhvate. U skladu sa MRS 28 , učešća u zajedničke poduhvate se u konsolidovanim finansijskim izveštajima obuhvataju primenom metode udela. Metod udela u konsolidovanim finansijskim izveštajima podrazumeva da se učešća u kapitalu pridruženih pravnih lica i zajedničkih poduhvata početno priznaju po nabavnoj vrednosti, a zatim se, za promene koje nastanu nakon datuma sticanja vrše korigovanja investitorovog udela u neto imovini entiteta u koji je investirano. Udeo društva u dobitku ili gubitku zajedničkog poduhvata u koji je investirano priznaje se u dobitku ili gubitku društva, dok se udeo društva u ukupnom ostalom rezultatu zajedničkog poduhvata priznaje u okviru ostalog rezultata matičnog društva.

Prema Pravilniku o Kontnom okviru i sadržini računa u Kontnom okviru za privredna društva, zadruge, i preduzetnike, na računu 041 - Učešća u kapitalu pridruženih pravnih lica i zajedničkim poduhvatima, iskazuju se učešća u kapitalu pravnih lica na čije poslovanje postoji značajan uticaj ili učešće u zajedničkim poslovima dva ili više lica, u skladu sa MRS 28 i MSFI 11. Prelazak sa metoda proporcionalne konsolidacije, koja se primenjivala prilikom sastavljanja konsolidovanih finansijskih izveštaja 2013. godine, predstavlja pro- menu računovodstvene politike u skladu sa Međunarodnim računovodstvenim standardom - MRS 8 Računovodstvene politike, promene računovodstvenih procena i greške. MSFI 11 je novi računovodstveni standard koji se primenjuje počev od sastavljanja finansijskih izveštavanja za 2014. godinu. U skladu sa paragrafom 19 MRS 28, entitet računovodstveno evidentira promenu računovodstvene politike koja proizilazi iz početne primene nekog MSFI u skladu sa konkretnim prelaznim odredbama, ako ih ima, u tom MSFI.

Zakon o privrednim društvima pod pojmom statusne promene podrazumeva samo promene $\mathrm{u}$ kojima dolazi do prenosa imovine sa jednog privrednog društva na drugo ili više drugih, ali ne i promene u kojima učestvuje samo jedno privredno društvo, tako što ono menja svoj status. Zakonodavac uvek ima ovlašćenje da odredi značenje pojmova za potrebe određenog zakona, kao što je učinjeno i u Zakonu. Tako je iz sadržine pojma statusne promene isključena promena pravne forme (tzv. transformacija), iako se u literaturi i ona obično podvodi pod kategoriju statusne promene. Iz pojma statusne promene isključene su i promene čije se pravno dejstvo sastoji u promeni nekih obeležja privrednog društva (npr. promena poslovnog imena, sedišta, strukture organa upravljanja i drugo).

\section{INFORMACIJE U KONSOLIDOVANIM FINANSIJSKIM IZVEŠTAJIMA I EVROPSKA PRAKSA}

Francuska i Velika Britanija nemaju posebnih odredbi o povezanim društvima, ali su putem računovodstvenog $i$ berzanskog prava razvile pravila o konsolidaciji godišnjih finansijskih izveštaja pridruženih, zavisnih kompanija i obavezi izveštavanja o sticanju udela. U Evropskoj uniji (EU) se nemački model uređenja zavisnih i pridruženih društava pokazao neprihvatljivim, pa je naglasak dat na transparentnosti povezanih društava kroz konsolidovanje finansijskih izveštaja. Neuporedivost finansijskih izveštaja privrednih društava i činjenica da su zemlje članice EU postavljale različite regulatorne zahteve u području konsolidovanih bilansa imalo je za posledicu da se usvoji Sedma direktiva 13.06.1983. godine. Odredbe nadnacionalnog akta u tadašnjoj Evropskoj ekonomskoj zajednici (EEZ), dovele su do radikalnih promena u praksi konsolidovanja finansijskih izveštaja kod svih zemalja članica, koje su bile primorane da ujednače regulativu. Navedena direktiva reguliše konsolidovanje računa, određuje identifikaciju grupa, krug konsolidovanja, obavezu da se pripreme, podležu reviziji, publikuju grupni finansijski izveštaji i metode vezane za konsolidaciju. Protekom vremena stručna javnost je ukazivala na neke nedostatke direktive, od kojih se ističe grupa eminentnih stručnjaka za pravo privrednih društava (High Level Group of Company Law Experts) je u svom Izveštaju o savremenom okviru za regulisanje kompanijskog prava u EU (Izvješće Winter) predložila revizija odredbi Sedme direktive te primenu 
Međunarodnih računovodstvenih standarda u izradi konsolidovanih finansijskih izveštaja (Jurić, 2006). Najznačajnija novina u ovoj deceniji u oblasti računovodstvene regulative EU u bilo je donošenje nove Direktive 2013/34/EU juna 2013. godine. Države članice svoje regulative treba da usklade i da primena počne od finansijskih izveštaja 2016. godine. Nova Direktiva bi trebala da smanji jaz koji je postojao između starih direktiva (IV i VII) i MSFI, na jednoj strani, i US GAAP, na drugoj strani. U delu koji se odnosi na konsolidovane finansijske izveštaje matična kompanija je definisana kao kompanija koja ima kontrolu nad najmanje jednim zavisnim preduzećem koje je stečeno kupovinom većine glasačkih prava, dominantnim uticajem ili postavljanjem upravljačkih struktura u stečenom preduzeću. Konsolidovani finansijski izveštaji trebali bi prikazati aktivnosti matičnog preduzeća i njegovih zavisnih preduzeća kao jedinstvenog ekonomskog subjekta (grupe). Preduzeća koja kontroliše matično preduzeće trebalo bi smatrati zavisnim preduzećima. Kontrola bi se trebala zasnivati na držanju većine glasačkih prava, ali kontrola može postojati $i$ ako postoje ugovori s akcionarima ili članovima tog preduzeća. U određenim okolnostima kontrola se može izvršavati i kada je matično preduzeće vlasnik manjine akcija ili udela ili nijedne akcije odnosno nijednog udela u zavisnom preduzeću. Države članice bi trebale zahtevati da preduzeća koja ne podležu kontroli, ali kojima se upravlja na jedinstvenoj osnovi ili imaju zajedničko administrativno, upravljačko ili nadzorno telo budu obuhvaćena konsolidovanim finansijskim izveštajem. Zavisno preduzeće koje je i samo matično preduzeće trebalo bi sastavljati konsolidovane finansijske izveštaje. Ipak, države članice trebale bi imati pravo izuzeti takvo preduzeće od obaveze sastavljanja konsolidovanih izveštaja u određenim okolnostima, pod uslovom da su njegovi članovi i treće strane dovoljno zaštićeni. Računovodstvena direktiva dozvoljava i određena izuzeća u vezi sastavljanja konsolidovanih finansijskih izveštaja. Mala i srednja preduzeća su izuzeta od obaveze sastavljanja konsolidovanih finansijskih izveštaja osim ako je neko od povezanih preduzeća subjekt od javnog interesa. Korisnicima finansijskih izveštaja malih i srednjih preduzeća nisu potrebne složene informacije, a i sastavljanje konsolidovanih finansijskih izveštaja može iziskivati dosta vremena i napora.

Prednosti procesa harmonizacije EU i finansijskog izveštavanja u Srbiji se prepoznaju kao direktne i kao indirektne koristi. Direktne koristi su prerastanje srpske računovodstvene regulative u nadnacionalnu evropsku regulativu, znatno lakše međunarodno poređenje i revizije finansijskih izveštaja, pojednostavljena izrada konsolidovanih izveštaja, niži troškovi prilagođavanja zahtevima kvalitetnog finansijskog izveštavanja, kontinuirano unapređenje računovstvene struke, veća dostupnost i šira raspoloživost i primena aktuelne međunarodne računovodstvene regulative i dr. Indirektne koristi su priliv stranih investicija, veći kreditni rejting zemlje, niži rizik ulaganja i cene kapitala, masovnije učešće i nastupi na međunarodnim tržištima kapitala, povećanje ukupne efikasnosti na finansijskom tržištu.
Izveštaj o poslovanju (management report) predstavlja bitan element finansijskog izveštavanja u preduzeću jer uključuje objektivan pregled razvoja i rezultata poslovanja zajedno sa opisom osnovnih rizika i neizvesnostima kojima je izloženo. Rizici u savremenim uslovima poslovanja nameću obavezu da informacije ne bi trebalo ograničiti samo na finansijski aspekt poslovanja, već one treba da uključe i analizu ekoloških i društvenih aspekata poslovanja koje su potrebne za razumevanje razvoja, poslovnih rezultata odnosno položaja preduzeća. Ovaj izveštaj treba da sadrži i sledeće: bilo koji događaj koji se desio nakon završetka poslovne godine, aktivnosti koje se odnose na istraživanje i budući razvoj u preduzeću, obelodanjivanje informacija o otkupu sopstvenih akcija, informacije o korišćenju finansijskih instrumenata kada oni značajno utiču na pozicije u bilansima i drugo. Poslovno okruženje se suočava sa sve većim rizicima i nesigurnostima što iziskuje pružanje sadržajnijih informacija o poslovanju, finansijskom položaju i razvoju analizirajući ključne finansijske i nefinansijske aspekte poslovanja. Cilj sastavljanja izveštaja o poslovanju se ogleda u pružanju svih navedenih informacija menadžmentu preduzeća kako bi se sagledala šira slika poslovanja i donele kvalitetne odluke o kontinuiranosti poslovanja i daljem razvoju.

Aktuelni zakon o računovodstvu iz 2013. godine bio je predmet usklađivanja sa Četvrtom (78/660/EC) i Sedmom direktivom (83/349/EEC) EU koje uređuju oblast korporativnog računovodstva. S obzirom da je u međuvremenu doneta nova Direktiva o računovodstvu (2013/34/EU) čija je primena obavezna za članice EU počev od 2016. godine, jasno je da ni ovo zakonsko rešenje neće potrajati. Istovremeno doneti Zakon o reviziji bio je predmet usklađivanja sa Osmom direktivom EU (2006/43/EC) koja uređuje oblast zakonske revizije, ali u ovom slučaju je zakon u potpunosti usklađen. Međutim, aktuelni globalni normativni okvir se stalno menja pa je 16.4.2014. godina doneta Direktiva o izmeni Osme direktive (2014/56/EU), čija je primena obavezna za članice EU počev od juna 2016. godine. Imajući u vidu navedeno, kao i potrebu daljeg usklađivanja Zakona o računovodstva i Zakona o reviziji da novodonetim direktivama EU koje uređuju oblast korporativnog računovodstva i revizije, Ministarstvo finansija će morati zbog postizanje potpuno usklađenog zakonskog okvira u oblasti računovodstva i revizije sa zakonodavstvom EU, najkasnije u narednih dve godine pripremiti predloge za izmene i dopune krovnih finansijskih zakona u Srbiji.

$\mathrm{Da}$ bi investitori doneli odluku o ulaganju kapitala u određeno preduzeće, informacije koje su prezentovane u finansijskim izveštajima moraju biti ne samo relevantne, već i verodostojno prezentovane. Verodostojna prezentacija pretpostavlja da su informacije tačne, odnosno bez grešaka, potpune, neutralne i obezbeđuju adekvatnu osnovu za donošenje odluka. Iako je suština zahteva za potpunošću finansijskih izveštaja jednaka, nezavisno od toga da li je reč o finansijskim izveštajima pojedinačnih pravnih lica ili konsolidovanim finansijskim izvšetajima, njegovo ispunjenje se postiže na različite načine. Naime, finansijski izveštaji pojedinačnih 
pravnih lica se smatraju potpunim ako su u njima iskazani sva imovina, obaveze i kapital na dan izveštavanja kao i svi prihodi i rashodi u toku izveštajnog perioda, i obuhvaćene posledice svih na njima nastalih poslovnih transakcija tokom izveštajnog perioda. Takođe, događaji nakon datuma izveštavanja koji su sastavni deo napomena uz finansijske izveštaje mogu imati veliki značaj na donošenje odluka o investiranju jer mogu ukazati na aktivnosti preduzeća nakon perioda izveštavanja (novi kreditni aranžmani, isplata dividende, značajne nabavke stalnih sredstava itd.).

Potpunost konsolidovanih finansijskih izveštaja biće ostvarena samo ako su:

- potpuni finansijski izveštaji zavisnih/pridruženih preduzeća u okviru grupe i

- u konsolidovanje uključena sva zavisna/pridružena preduzeća koja čine grupu kao ekonomsku celinu.

Finansijski izveštaji pojedinačnih preduzeća pored toga što moraju sadržati verodostojne prezentacije u njima iskazanih informacija, predstavljaju osnovu za sastavljanje, prezentaciju i obelodanjivanje konsolidovanih finansijskih izveštaja. Pored tačnog prikazivanja finansijskog položaja i uspešnosti svog poslovanja, pojedinačni finansijski izveštaji zavisnih preduzeća moraju obelodaniti sve svoje međusobne transakcije kako sa matičnim tako i sa svim ostalim preduzećima unutar grupe. Ipak, potpunost pojedinačnih finansijskih izveštaja ne obezbeđuje i potpunost konsolidovanog izveštaja o finansijskom položaju na kraju perioda i konsolidovanog izveštaja o ukupnom rezultatu u toku perioda, a time ni njihovu potpunost. Potpunost konsolidovanih finansijskih izveštaja zavisi i od isključenosti svih preduzeća nad kojima matično ima kontrolu u krug konsolidacije. Izostavljanje samo jednog preduzeća koje se nalazi pod kontrolom matičnog iz kruga konsolidovanja ili uključivanje u krug konsolidovanja preduzeća koja ne čine deo grupe kao ekonomske celine ima za posledicu prezentaciju netačnih konsolidovanih finansijskih izveštaja. Zbog postojanja različitih načina na koji se može uspostaviti kontrola nad drugim preduzećem s jedne i izuzetne važnosti da se njeno postojanje može pouzdano utvrditi s druge strane, definisanje kriterijuma za identifikovanje odnosa matično - zavisno preduzeće je više nego ozbiljan zadatak.

\section{IZAZOVI UKLJUČIVANJA STEČENIH PREDUZEĆA U KRUG KONSOLIDACIJE}

Zavisna preduzeća predstavljaju pravno samostalne ekonomske celine koja su povezana sa matičnim preduzećem putem vlasničkih hartija od vrednosti (akcija) ili putem različitih vrsta ugovora. Kupovinom odgovarajućeg paketa akcija tj. sticanjem kontrole nad preduzećem omogućuje se uticanj na njihovo poslovanje i donošenje odluka. Promena vlasništva u preduzećima podrazumeva obaveštavanje nacionalnih organa koji obavljaju nadzor i odobravaju svaku transakciju sticanja preduzeća.
Proces uključivanja stečenih preduzeća u krug konsolidacije počinje od datuma kada investitor stekne kontrolu nad preduzećem a prestaje gubitkom iste. Datum sticanja preduzeća je veoma bitan za izradu konsolidovanih finansijskih izveštaja grupe jer sva imovina, obaveze i kapital stečenog preduzeća na taj datum ulazi u konsolidovane finansijske izveštaje. $S$ druge strane ostvareni prihodi i rashodi stečenog preduzeća do trenutka sticanja preduzeća se ne uključuju u konsolidovane finansijske izveštaje, već se uključuju samo oni prihodi i rashodi od trenutka sticanja kontrole nad preduzećem do sledećeg datuma sastavljanja konsolidovanih finansijskih izveštaja. Ukoliko je datum sticanja preduzeća 31. decembar izveštajne godine, u konsolidovani izveštaj o ukupnom rezultatu neće biti uključeni prihodi i rashodi tj. neto rezultat stečenog preduzeća, ali će sve pozicije iz pojedinačnog izveštaja o finansijskoj poziciji stečenog preduzeća biti prikazane u konsolidovani izveštaj o finansijskoj poziciji. U navedenoj situaciji, posredno će neto rezultat preduzeća koje ulazi u krug konsolidacije biti uključeno u konsolidovani izveštaj o finansijskoj poziciji grupe i to preko neraspoređene dobiti.

Pre samog uključivanja stečenih preduzeća u krug konsolidacije potrebno je analizirati pojedinačne finansijske izveštaje istih kako bi se identifikovale pozicije u njima koje reprezentuju proknjižene poslovne transakcije. Ukoliko se kupuje preduzeće iz iste ili slične delatnosti proces konsolidacije ne mora biti toliko složen jer će se jednostavnim zbrajanjem istovrsnih pozicija dobiti konsolidovani izveštaj. Međutim, ukoliko je delatnost poslovanja stečenog preduzeća potpuno različita od osnovne delatnosti matičnog, utoliko je izrada konsolidovanih finansijskih izveštaja složenija. U takvoj situaciji je neophodno definisati nove pozicije u napomenama uz konsolidovane izveštaje koje bi prikazivale transakcije koje ne pripadaju osnovnoj delatnosti matičnog preduzeća.

Pored navedenog, računovodstvene politike stečenih preduzeća se mogu u mnogome razlikovati od politika matičnog preduzeća. Prilagođavanje istih može dovesti do izmena načina knjiženja ali i prikazivanja pozicija u finansijskim izveštajima zavisnih preduzeća. Matično preduzeće može iskoristiti svoju moć i uskladiti računovodstvene politike grupe i zavishih preduzeća. Takođe, različitost u politikama se može javiti usled različite oblasti poslovanja između matičnog i zavishih preduzeća. U takvoj situaciji računovodsteve politike grupe će biti proširene uvođenjem novih paragrafa koji objašnjavaju suštinu različitih delatnosti poslovanja kod zavisnih preduzeća. S obzirom na to da pri izradi konsolidovanih finansijskih izveštaja treba voditi računa o eliminisanju svih međusobnih transakcija, prilikom uvođenja stečenih preduzeća u krug konsolidacije neophodno je identifikovati transakcije između matičnog i novog zavisnog preduzeća. Na ovaj način se u konsolidovanim finansijskim izveštajima ne prikazuju ulaganja, potraživanja i obaveze, prihodi i rashodi koji su nastali između matičnog i zavisnih preduzeća, budući da bi oni predstavljali transakcije i poslovne događaje koji se odvijaju unutar jednog računovodstvenog subjekta. 
Konsolidovani finansijski izveštaji imaju nekoliko ograničenja od kojih se mogu izdvojiti sledeća (Mijatović, 2012):

a) u konsolidovanim finansijskim izveštajima nisu objavljeni finansijski rezultati i finansijska situacija članica grupe pa se dobri ili loši rezultati pojedinog preduzeća mogu skrivati iza rezultata drugih članova grupe,

b) konsolidovani zadržani dobici nisu u celosti raspoloživi za raspodelu dividendi jer deo može predstavljati udeo matičnog preduzeća u neraspoređenim dobicima zavisnih preduzeća,

c) finansijski pokazatelji izrađeni na osnovu konsolidovanih finansijskih izveštaja su agregatni pokazatelji koji ne predstavljaju pojedina zavisna preduzeća kao ni matično preduzeće,

d) konsolidovani finansijski izveštaji ne daju dodatne informacije neophodne za kontrolisanje članica grupe pa se iste moraju tražiti u odvojenim finansijskim izveštajima ili u napomenama uz pojedinačne finansijske izveštaje članica grupe.

Sticanje vlasništva u preduzeću utiče i na izbor metoda konsolidacije. U zavisnosti od procenta vlasništva u stečenom preduzeću može se primeniti metod potpune konsolidacije ili metod udela. U dosadašnjim istraživanjima (Guilding et al., 2000) utvrđena je povezanost veličine preduzeća i korišćenja sofisticiranih računovodstvenih metoda na način da veća preduzeća više koriste razvijene računovodstvene instrumente u funkciji upravljanja i kontrole poslovanja. Kompanija "Telekom Srbija" a.d. koristi metod potpune konsolidacije kod zavisnih preduzeća u kojima ima preko 50\% vlasništva. Navedena metoda podrazumeva potpuno eliminisanje svih međusobnih transakcija. Metoda udela se koristi kod pridruženih preduzeća tj. kod preduzeća gde vlasništvo iznosi tačno $50 \%$. Ova metoda podrazumeva priznavanje $50 \%$ ostvarenog rezultata pridruženog preduzeća u konsolidovani izveštaj o ukupnom rezultatu. Priznat neto rezultat se evidentira i u konsolidovanom izveštaju o finansijskoj poziciji i to povećanjem/smanjenjem učešća u pridruženom preduzeću u iznosu priznatog neto dobitka/neto gubitka.

Sama akvizicija tj. kupovina novih preduzeća iziskuje sveobuhvatnu analizu njihovih poslovanja putem due diligence izveštaja gde se ispituje komercijalni, finansijski i pravni aspekt poslovanja pre procesa prodaje. Nezavisne konsultantske kompanije putem navedenog izveštaja mogu olakšati investitoru donošenje odluke o investiranju i postizanju najbolje moguće kupoprodajne cene. Prilikom donošenja odluke o kupovini investitor sagledava budući efekat na poslovanje grupe koji će se ostvariti uključuvanjem još jednog preduzeća u krug konsolidacije.

Definisanje kupoprodajne cene podrazumeva i njenu alokaciju kroz različita sredstva i obaveze stečenih u transakciji kupovine preduzeća. Kao identifikovana (prepoznatljiva) sredstva i obaveze trebalo bi da budu priznata sva sredstva i obaveze koje su postojale u ciljnom preduzeću na dan akvizi- cije, i ona bi trebalo da budu procenjena po fer vrednosti koja je odgovarala njihovom stanju na taj dan. U identifikovana sredstva i obaveze trebalo bi da budu uključene i one komponente koje nisu prethodno, odnosno pre dana akvizicije, bile priznate u finansijskim izveštajima ciljnog preduzeća. Uključivanje ovih stavki u identifikovana sredstva i obaveze je neophodno kako bi se stekao potpun i realan uvid u finansijski položaj stečenog preduzeća. Goodwill predstavlja višak troška sticanja iznad udela grupe u neto fer vrednosti prepoznatljivih sredstava stečenih preduzeća.

Telekom Srbija ima učešće u vlasništvu sledećih zavisnih i pridruženih preduzeća na dan 31. decembra 2015. godine:

\begin{tabular}{lcc}
\hline Zavisna pravna lica & Iznos & Učešće \% \\
\hline „Telekom Srpske“ a.d. & $56.933 .379 .802,56$ & $65 \%$ \\
\hline „M:TEL“ d.o.o. & $3.176 .710 .900,70$ & $83 \%$ \\
\hline „MTS banka“ a.d. & $1.306 .839 .769,00$ & $76 \%$ \\
\hline „HD WIN“ d.o.o. & $790.475 .853,44$ & $51 \%$ \\
\hline ”TS:NET“ BV & $122.486 .916,14$ & $100 \%$ \\
\hline ”Telus“ a.d. & $9.030 .450,94$ & $100 \%$ \\
\hline „MTS“ d.o.o. Severna & $3.006 .885,00$ & $100 \%$ \\
\hline $\begin{array}{l}\text { Ditrovica } \\
\text { Genedia group SA }\end{array}$ & $4.728 .100,00$ & $50 \%$ \\
\hline \begin{tabular}{l} 
GO4YU d.o.o. \\
\hline
\end{tabular}
\end{tabular}

Izvor: Konsolidovani finansijski izveštaj "Telekom Srbija” a.d. za godinu koja se završava 31. decembra 2015. godine u skladu sa računovodstvenim propisima Republike Srbije

Preduzeće za telekomunikacije "Telekom Srbija" a.d. je $\mathrm{u}$ decembru 2014. godine izvršilo akviziciju tadašnje Dunav banke (danas MTS banke). Ukupan trošak sticanja za 56\% kapitala je iznosio RSD 1,053,323 hiljade dok je fer vrednost stečenih neto sredstava (na osnovu izveštaja o alokaciji kupoprodajne cene) iznosila RSD 1,829,892 hiljade. Manjinski interes na osnovu učešća u neto identifikovanoj imovini je iznosio RSD 808,995 hiljada. Identifikovani goodwill je iznosio RSD 32,426 hiljada i priznat je u konsolidovanom izveštaju o finansijskoj poziciji grupe. S obzirom da je akvizicija izvršena u decembru 2014. godine negativan neto rezultat banke za navedenu godinu nije uključen u konsolidovani izveštaj o ukupnom rezultatu. Možemo zaključiti da je početni efekat uključivanja stečenog preduzeća u krug konsolidacije vidljiv bio samo u konsolidovanom izveštaju o finansijskoj poziciji grupe u vidu zbrajanja pozicija pojedinačnog izveštaja Dunav banke, eliminisanja međusobnih transakcija, priznavanja stečenog goodwill-a kao nematerijalne imovine, ali i priznavanja identifikovanih potraživanja i obaveza kroz alokaciju kupoprodajne cene. 
Osnovni cilj kupovine Dunav banke od strane Telekom Srbija je bio ulazak na bankarsko tržište (mobilno i elektronsko), dalje jačanje tržišne pozicije i širenje baze korisnika grupe. Spoj bankarskih i telekomunikacionih usluga predstavlja osnovu za unapređenje poslovanja grupe kao i pružanje novih usluga na tržištu. Preduzeće za telekomunikacije "Telekom Srbija" a.d. je na taj način dobilo licencu za rad na finansijskom tržištu, s obzirom da obezbeđena infrastruktura za nezavisno pružanje finansijskih usluga: infrastruktura banke zajedno sa obučenim osobljem u uslovima kad je lokalna konkurencija već realizovala ovaj poslovni model (Telenor banka). Takođe, konkurentnost u telco industriji u našoj zemlji je izuzetno velika tako da pružanje širokog spektra različitih usluga omogućuje kompaniji kontinuirani rast. Sa druge strane, i banka je prodajom svog kapitala omogućila veću efikasnost u poslovanju jer je uz jakog partnera stvorila osnove za povećanje tržišnog udela.

Rizici koji se javljaju prilikom sticanja preduzeća i njihovog uključivanja u krug konsolidacije su raznovrsni i ogledaju se pre svega u umanjenju performansi poslovanja grupe kao ekonomke celine u vidu niže EBIT, EBITDA i neto dobiti ukoliko stečeno preduzeće u svom poslovanju iskazuje slabije performanse od željenih i zatečenih prilikom analize i kupovine. Takođe, željeni sinergijski efekat koji treba da poboljša uspešnost poslovanja grupe se može ostvariti u kasnijem periodu od planiranog usled loše uspostavljene koordinacije u aktivnostima između matičnog i stečenog preduzeća. Rizici u savremenim uslovima poslovanja i izazovi konsolidacije u TSGrupi je i nerazumevanje regulatora o kompleksnosti sprovođenja promena u retkim multinacionalnim kompanijama Srbije kojima je matično društvo upravo u Republici Srbiji, uopšte velikim privrednim gigantima, a koje se ogledaju kroz česte izmene kontnog okvira (sedam u poslednjih 10 godina: Pravilnik o Kontnom okviru i sadržini računa u Kontnom okviru za privredna društva, zadruge, druga pravna lica i preduzetnike (“Službeni glasnik RS", br. 114/06, 119/08, 9/09, 4/10, 3/11 i 101/12) i Pravilnik o kontnom okviru i sadržini računa u kontnom okviru za privredna društva, zadruge i preduzetnike (Sl. glasnik RS br. 95/14). Imajući u vidu da za banku koja je deo TS grupe, a ima poseban kontni okvir (dva puta menjan u poslednje dve godine "Službeni glasnik RS", br. 71/2014 i 135/2014), da se regulativa menja i na kraju godine, a mora se primeniti na sastavljanje finansijskih izveštaja za godinu u kojoj su doneti novi propisi unosi se zabuna i komplikuje proces kvalitetnog knjigovodstvenog obuhvatanja poslovnih promena i sastavljanja finansijskih izveštaja.

\section{EKONOMSKE POSLEDICE PRESTANKA KONSOLIDOVANJA PREDUZEĆA NAKON OTUĐENJA IZ GRUPE}

Statusne promene u grupi podrazumevaju i otuđenja preduzeća koja ulaze u krug konsolidacije putem prodaje istih ili pak prenosom vlasništva na drugo zavisno preduzeće. Datum gubitka kontrole utiče na promene u procesu konsolidacije i izrade konsolidovanih finansijskih izveštaja grupe. Naime, na datum gubitka kontrole konsolidovani izveštaj o finansijskoj poziciji neće uključivati pozicije aktive, pasive i kapitala preduzeća koje više nije u vlasništvu matičnog preduzeća tj. prestaje se sa priznavanjem imovine i obaveza zavisnog preduzeća po njihovim knjigovodstvenim vrednostima. $S$ druge strane, ukupni prihodi i rashodi, a samim tim i neto rezultat otuđenih preduzeća se priznaje do trenutka gubitka kontrole.

Kod donošenja odluke o otuđenju preduzeća matično preduzeće bi trebalo da se rukovodi isključivo ekonomskim razlozima. Ukoliko zavisno preduzeće većinu svojih prihoda ostvaruje u transakcijama sa matičnim preduzećima, njegov doprinos uspešnosti poslovanja grupe ne može biti značajan jer će nakon eliminisanja međusobnih transakcija njihov rezultat koji se priznaje u konsolidovanim finansijskim izveštajima biti značajno niži a možda čak i negativan. U takvim slučajevima je bolje otuđiti preduzeće iz grupe nego priznavati njegovu nemogućnost ostvarivanja pozitivnih rezultata u transakcijama sa trećim licima.

Međutim, postoje i situacije gde je zadržavanje preduzeća sa dominatnim prihodima od matičnog preduzeća u grupi pozitivno ukoliko su usluge koje ono pruža značajne za grupu u smislu njihovog kombinovanja sa ostalim uslugama matičnog preduzeća. Kombinovanje raznovrsnih usluga može doprineti ostvarivanju dodatnih prihoda za grupu kao ekonomsku celinu (primer zavisnog preduzeća HD WIN koje se nalazi u Telekom Srbija Grupi a koje se bavi pružanjem prenosa sportskih takmičenja). Doprinos navedenog preduzeća neto rezultatu grupe nakon eliminisanja međusobnih transakcije je negativan ali je prenos sportskih takmičenja jedan od razloga većeg broja pretplatnika multimedijalnih usluga koje pruža Telekom Srbija a samim tim i većih prihoda po ovom osnovu.

\section{ZAKLJUČAK}

U savremenim uslovima poslovanja donošenje poslovnih odluka se u velikoj meri zasniva na objektivnom i istinitom finansijskom izveštavanju i potrebno je sprovoditi u skladu s pravilima struke. Globalizovano poslovanje na većem broju tržišta, zemalja i portfelj investicija u različitim privrednim delatnostima posebno aktuelizuje pitanje konsolidovanja finansijskih izveštaja. U skladu sa tim izrada konsolidovanih finansijskih izveštaja u kojima se prikazuje uspešnost poslovanja kao i imovinski položaj grupe (uključena stečena/otuđenja preduzeća) ima veliki značaj na donošenje strateških i operativnih odluka u vezi budućeg poslovanja. $U$ ovome radu je dat pregled računovodstvenih metoda za poslovne kombinacije, računovodstvenog tretmana pojedinih bilansnih pozicija te konsolidacijskih postupaka nakon obavljene poslovne kombinacije. Naučni doprinos ovog rada proističe iz činjenice da su pojedinačni finansijski izveštaji u evropskoj praksi mnogo 
detaljnije regulisani od konsolidovanih finansijskih izveštaja. Razlozi su mnogobrojni, prvo zbog fiskusa koji je zainteresovan upravo za pojedinačne poslovne entitete u svojoj jurisdikciji, a ne za grupu, a drugo i stejkholdere (ili u slučaju Telekom Srbija potencijalne kupce) koji analiziraju poslovanje (s obzirom na to da većina pravnih ugovora sa poveriocima, dobavljačima ili klijentima sklapa se na nivou pojedinačnih poslovnih entiteta, i matičnog društva, a ne TS grupe).

Rizici koji se javljaju prilikom donošenja odluka o kupovini/otuđenju preduzeća se ogledaju kroz postizanje željenog pozitivnog ili pak ostvarenju negativnog doprinosa uspešnosti poslovanja grupe kao celine. Ponekad je zadržavanje preduzeća u grupi suprotno ekonomskim principima ali se uvek treba sagledati šira slika poslovanja grupe. Kombinovanjem raznovrsnih vrsta usluga u odgovarajući paket postiže se veći sinergijski efekat u smislu privlačenja većeg broja korisnika a samim tim i većih prihoda za grupu kao ekonomsku celinu.

\section{LITERATURA}

Đorđević, S. (2008). Bilansni aspekti merdžera i akvizicija. Računovodstvo, 3(4). Beograd: Savez računovođa i revizora Srbije.

EUR-lex. (2013). Direktiva o računovodstvu (2013/34/EU). Preuzeto 12. Juna 2016. sa http://eur-lex.europa.eu/legal-content/

Jurić, D. (2006). Transparentnost stastusnih i financijskih odnosa povezanih društava. Zbornik Pravnog fakulteta Sveučilišta u Rijeci, 27(2), 939-984.
Mijatović, E. (2012). Računovodstveno evidentiranje restrukturiranja poduzeća tehnikama spajanja i preuzimanja poduzeća. Učenje za poduzetništvo, 2(2), 147-156.

Ramljak, B., \& Rogošić, A. (2013). Interno orijentirano računovodstvo u provedbi strategije kvalitete. Ekonomski pregled, 64(1), 30-48.

Službeni glasnik Republike Srbije. (2013). Zakon o računovodstvu iZakon o reviziji. Službeni glasnik RS br. 62/13.

Službeni glasnik Republike Srbije. (2014). Rešenje o utvrđivanju prevoda Konceptualnog okvira za finansijsko izveštavanje i osnovnih tekstova Međunarodnih računovodstvenih standarda, odnosno Međunarodnih standarda finansijskog izveštavanja. Službeni glasnik RS br. 35/14.

Službeni glasnik Republike Srbije. (2014). Pravilnik o Kontnom okviru i sadržini računa u Kontnom okviru za privredna društva, zadruge, i preduzetnike. Službeni glasnik RS, br. 95/2014.

Stojilković, M. (2016). New accounting directive with the aim to improve financial reporting in the European Union. Teme, XL(1), 103-122.

Telekom Srbija. (2015). Konsolidovani finansijski izveštaj "Telekom Srbija" a.d. za godinu koja se završava 31. decembra 2015. godine u skladu sa Računovodstvenim propisima Republike Srbije. Preuzeto 15. juna 2016. sa http://static.mts. rs/pdf/poslovanje/Telekom_Srbija_Konsolidovani_statutarni_2015.pdf?d=False\&h=636071146708400000

Škarić Jovanović, K. (2013). Novi kriterijumi za određivanje kruga konsolidovanja u MSFI 10: Konsolidovani finansijski izveštaji. Financing: Naučni časopis za ekonomiju, 1(13), 18-25.

\section{ACQUISITION OF NEW AND DISPOSAL OF EXISTING COMPANIES AS FACTORS IN CONSOLIDATED FINANCIAL STATEMENTS PREPARATION - CASE STUDY OF TELEKOM SERBIA A.D.}

\begin{abstract}
:
Consolidated financial statements preparation represents a legal obligation of the parent company, which has a corresponding form of control over subsidiaries. The very process of consolidation involves combining the individual financial statements of the Group entities while eliminating their mutual business transactions. The aim of the paper is to point to the problem of introducing the acquired companies in consolidation, particularly those which operate in activities that do not correspond to the activities of the parent company, which prepares consolidated financial statements. The issue of uniformity of accounting policies, valuation and balance sheet and income statement presentation, as well as the impact of acquired/disposed companies on the assets and business performance of the Group, require research based on different situations in practice. Getting companies into consolidation circle or eliminating them is aimed at improving and optimizing the business performance of the Group. Examples in practice show that there are cases where the mentioned processes have resulted in different performance, which points to the fact that the decision about "widening" or "narrowing" the circle of consolidation must be based on the basic economic principles.
\end{abstract}

Keywords:

Group status changes, consolidation, financial reporting, accounting standards. 